\title{
Analisis Kemampuan Koneksi Matematik dan Self Confidence Siswa SMP melalui Model Pembelajaran Think Pair Share
}

\author{
Iis Rosdianti ${ }^{1}$, Nisa Fitri Alfiyah ${ }^{1}$, Luvy Sylviana Zanthy ${ }^{1}$ \\ 1IKIP Siliwangi Bandung, Jl. Terusan Jend. Sudirman, Baros, Kec. Cimahi Tengah, Kota \\ Cimahi, Jawa Barat 40521 \\ *Correspondent Author: iisrosdianti9@gmail.com
}

\begin{abstract}
Abstrak
Penelitian ini bertujuan untuk mendeskripsikan kemampuan koneksi matematik dan self confidence siswa melalui model pembelajaran Think Pair Share (TPS). Penelitian ini merupakan penelitian deskriptif kualitatif. Instrumen yang digunakan dalam penelitian ini yaitu tes uraian dan angket self confidence. Dari hasil penyelesaian tes uraian siswa, diperoleh bahwa tingkat kemampuan koneksi matematik melalui model pembelajaran Think Pair Share siswa SMP tersebut masih tergolong rendah. Hal tersebut dipengaruhi oleh beberapa faktor, salah satunya siswa kurang memahami materi serta siswa tidak mampu mentransformasikan persoalan yang diajukan ke dalam pengetahuan yang dimilikinya. Hal itu dapat terlihat dari kesalahan siswa dalam pengerjaan tes uraian. Sementara itu, meskipun hasil tes uraian koneksi matematik masih rendah, namun skala sikap self confidence siswa tersebut sudah cukup baik yaitu 60,96\%.
\end{abstract}

Kata Kunci: Koneksi Matematik, Self Confidence, Think Pair Share.

\begin{abstract}
This study aims to describe the ability of mathematical connections and students' self confidence through the Think Pair Share (TPS) learning model. This research is a qualitative descriptive.. The instruments used in this study were the description test and self confidence questionnaire. From the results of the completion of the student description test, it was found that the level of mathematical connection ability through the Think Pair Share learning model for junior high school students is still relatively low. This is influenced by several factors, one of them is students' lack of understanding of the material and students are not able to transform the problem posed into the knowledge they have. This can be seen from the mistakes of students in working on the test description. Meanwhile, even though the test results of the mathematical connection description are still low, the scale of the students' self-confidence attitude is good enough at $60.96 \%$.
\end{abstract}

Keywords: Mathematical Connection, Self Confidence, Think Pair Share.

\section{PENDAHULUAN}

Matematika merupakan mata pelajaran wajib dalam dunia pendidikan formal, dari mulai tingkat sekolah dasar, sekolah menengah hingga jenjang perguruan tinggi. Matematika juga tidak bisa lepas dalam kehidupan atau aktivitas sehari-hari manusia. Misalnya, dalam jual beli, penggunaan jasa angkutan umum, pengukuran berat badan dan tinggi badan, dan lain sebagainya. Mengingat besarnya peranan matematika dalam kehidupan sehari-hari, maka sudah seharusnya penyampaian dan pengajaran matematika menekanan pada apa yang siswa alami dalam kehidupan sehariharinya.

Berdasarkan pemaparan diatas, sudah seharusnya siswa dibekali dengan kemampuan-kemampuan matematik. Berkenaan dengan kemampuan 
matematik, The National Council of Teacher of Mathematics atau NCTM(Ni'mah, Setiawani, \& Oktavianingtyas, 2017)menyebutkan bahwa ada lima kemampuan dasar matematik, yaitu kemampuan pemecahan masalah (problem solving), penalaran dan bukti (reasoning and proof), komunikasi (communication), koneksi (connections) dan representasi (representation). Salah satu kemampuan dasar yang sangat penting dimiliki oleh siswa adalah kemampuan koneksi matematik karena dalam pembelajaran matematika setiap konsep satu berkaitan dengan konsep yang lainnya. Namun, dalam kenyataannya kemampuan koneksi matematik masih rendah (Adni, Nurfauziah, \& Rohaeti, 2018).

Hal ini sejalan dengan obeservasi yang dilakukan oleh Puteri \& Riwayati (2017)di SMP Negeri 15 Kota Bengkulu, yang mengatakan bahwa lemahnya kemampuan koneksi matematik siswa dapat dilihat dari ketidakmampuan siswa menghubungkan konsep atau materi yang telah dipelajari, sehingga membuat siswa kesulitan dalam mengerjakan soal yang diberikan guru. Hal ini dikarenakan sebagian besar proses pembelajaran siswa hanya mengikuti, mendengar dan menyalin dari apa yang diberikan oleh guru, yang mengakibatkan kemampuan koneksi matematik siswa tidak berkembang secara optimal. Maka dari itu dibutuhkan proses pembelajaran yang mampu merangsang dan bahkan melatih kemampuan koneksi matematik siswa, hal ini tentu menjadi tugas khusus bagi para guru.

Kemampuan koneksi matematik menurut Muchlis dkk (Nursaniah \& Yuspriyati, 2018) adalah suatu kemampuan untuk menghubungkan atau mengaitkan matematika dengan masalah kehidupan sehari-hari, serta mengaitkan matematika dengan disiplin ilmu lain. Menurut NCTM (Adni et al.,
2018) apabila siswa mampu menghubungkan ide-ide matematika maka pemahaman metematikanya akan semakin dalam dan bertahan lama karena siswa mampu menemukan hubungan antartopik dalam matematika, dengan konteks diluar matematika dan dengan pengalaman dalam kehidupan sehari-hari. Adapun indikator koneksi matematik menurut Maulana (Ulya \& Irawati, 2016) yaitu: (1) menggunakan koneksi antar topik matematika dan antartopik matematika dengan topik lain, dan (2) menggunakan matematika dalam bidang studi lain dan atau dalam kehidupan sehari-hari. Sementara itu, Hendriana, Roaheti dan Soemarmo (2017) merangkum indikator koneksi matematik sebagai berikut : (1) mencari hubungan antar berbagai representasi konsep dan prosedur, serta memahami hubungan antar topik matematika; (2) memahami representasi ekuivalen konsep yang sama, mencari koneksi satu prosedur ke prosedur lain dalam representasi yang ekuivalen; (3) mencari hubungan berbagai representasi antara konsep dan prosedur; (4) menggunakan matematika dalam bidang studi lain atau kehidupan sehari-hari; dan (5) menggunakan dan menilai keterkaitan antartopik matematika dan keterkaitan topik matematika dengan topik diluar matematika.

Beberapa penelitian terdahulu melakukan berbagai cara untuk meningkatkan kemampuan koneksi matematika siswa, seperti yang dilakukan oleh (Badjeber \& Fatimah, 2015) menggunakan model pembelajaran inkuiri, (Purwaningrum, 2016) menggunakan Circuit Learning, (Marsitin, 2016) dengan Problem Solving.

Selain aspek kognitif seperti koneksi matematik, aspek afektif juga miliki peranan yang penting dalam pembelajaran matematika. Selaras dengan hal tersebut, (Mahmuzah, Ikhsan, \& Yusrizal, 2014)juga mengemukakan 
bahwa ada aspek penting yang dapat menunjang pembelajaran matematika, salah satunya self confidence. Selaras dengan itu, Mahmudi (Fauziah, Maya, \& Fitrianna, 2018) mengemukakan bahwa pembelajaran matematikda tidak hanya mengembangkan aspek kognitif saja, tetapi juga aspek afektif, salah satunya kepercayaan diri (self confidence). Yates (Hendriana, Rohaeti dan Soemarmo, 2017) mengemukakan bahwa self confidence sangat penting untuk siswa agar bisa berhasil dalam matematika. Dengan adanya self confidence, diharapkan siswa akan lebih termotivasi dan tergerak keinginannya untuk belajar matematika sehingga prestasi belajar matematika akan dicapai dengan optimal.Beberapa pakar mendefinisikan pengertian self confidence dalam ungkapan yang beragam, namun semuanya memuat ciri yang sama yaitu rasa percaya terhadap kemampuan dan perasaan dirinya sendiri. Fitriani (Fauziah et al., 2018) mengemukakan self confidence dalam matematika adalah siswa memiliki kesanggupan, kemampuan belajar matematika yang baik, cepat dan pantang menyerah, serta memiliki rasa yakin dengan kemampuan matematika yang dimilikinya. Sementara itu (Surayya, Subagia, \& Tika, 2014) mengemukakan bahwa kepercayaan diri adalah kemampuan diri seseorang dan bertanggung jawab atas segala tindakan yang dilakukannya sehingga tidak perlu takut atau cemas terhadap hasil yang di dapat.

Hendriana, Rohaeti dan Soemarmo (2017) merangkum indikator utama dari self confidence sebagai berikut: (1) percaya kepada kemampuan sendiri, (2) bertindak mandiri dalam mengambil keputusan, (3) memiliki konsep diri yang positif, (4) beranimengemukakan pendapat.Untuk dapat menciptakan siswa yang memiliki kemampuan koneksi matematik disertai dengan self confidence yang baik, maka diperlukan sebuah proses pembelajaran yang dapat menunjang terbentuknya aspek kognitif dan afektif tersebut

Pembelajaran yang mampu merangsang atau melatih kemampuan kognitif siswa juga tidak lepas dari peran penerapan model pembelajarannya. Salah satu model pembelajaran yang dirasa cocok adalah model pembelajaran Think Pair Share. Think Pair Share merupakan model pembelajaran kooperatif yang mampu merangsang aktivitas berpikir siswa secara berpasangan dan berbagi pengetahuan dengan siswa lainnya (Lestari \& Yudhanegara, 2015).

Beberapa penelitian menyatakan bahwa model pembelajaran Think Pair Share dapat meningkatkan hasil belajar pada beberapa mata pelajaran. Seperti Suharlik (Nursaniah \& Yuspriyati, 2018) mengemukakan bahwa terdapat pengaruh model pembelajaran Think Pair Share terhadap daya retensi siswa dan kemampuan kognitif akademik hasil belajar siswa pada mata pelajaran biologi, (Boleng, 2014) dalam hasil penelitiannya model TPS meningkatkan kemampuan berpikir kritis.

Berdasarkan paparan tersebut maka keterbaruan pada penelitian ini yaitu penelitian ini menganalisis kemampuan koneksi matematika dan self confidence melalui model Think Pair Share (TPS).

\section{METODE}

Metode penelitian ini adalah metode deskriptif kualitatif. Sugiyono (Ulya \& Irawati, 2016) mengemukakan bahwa penelitian dekriptif merupakan suatu pengujian yang dilakukan untuk memperoleh keberadaan suatu variabel, baik satu variabel atau lebih (yang berdiri sendiri) tanpa dibandingkan atau dikaitkan dengan variabel lainnya. Maka dalam hal ini peneliti hanya berupaya menerangkan dan menjelaskan kemampuan kognitif beserta afektif siswa dalam matematik. Subjek penelitian ini adalah siswa kelas VII di 
SMP Budi Bakti Utama tahun ajaran 2018/2019 dengan sampel 19 siswa. Instrumen yang digunakan dalam penelitian ini berupa tes tulis uraian kemampuan koneksi matematik beserta angket self confidence. Instrumen tes memuat empat soal dari dua indikator koneksi matematik. Untuk menilai jawaban tes soal, penulis mengacu pada rubrik penskoran yang telah disediakan. Rubrik skor penilaian kemampuan koneksi matematik modifikasi dari Nursaniah (2018), adalah sebagai berikut :

Tabel 1. Skor Penilaian Kemampuan Koneksi Matematik

\begin{tabular}{cl}
\hline Skor & \multicolumn{1}{c}{ Respon Siswa } \\
4 & $\begin{array}{l}\text { Mengenal Konsep matematika, } \\
\text { memahami hubungan konsep dan } \\
\text { penggunaannya, disertai jawaban } \\
\text { benar }\end{array}$ \\
3 & $\begin{array}{l}\text { Sesuai kriteria namun jawaban } \\
\text { kurang tepat } \\
2\end{array}$ \\
$\begin{array}{l}\text { Sebagian besar tidak sama dengan } \\
\text { kriteria, tapi jawaban benar }\end{array}$ \\
1 & $\begin{array}{l}\text { Jawaban ada tetapi tidak sama } \\
\text { dengan kriteria yang sudah } \\
\text { ditentukan } \\
\text { Tidak Ada Jawaban }\end{array}$ \\
\hline
\end{tabular}

Tahapan selanjutnya adalah penyusunan angket self confidence, angket yang digunakan merupakan angket modifikasi dari Hendriana (Hendriana, Rohaeti dan Soemarmo, 2017) yang terdiri dari 38 pernyataan. Dalam setiap pernyataan terdapat empat alternative respon atau jawaban yaitu sangat satuju (SS), setuju (S), tidak setuju (TS) dan sangat tidak setuju (STS). Skor yang diberikan untuk skala sikap pada jawaban dalam pernyataan positif yaitu 4,3,2,1 dan sebaliknya $1,2,3,4$ untuk pernyataan negatif. Untuk melihat self confidence siswa penulis mengklasifikasikannya sebagai berikut:

Tabel 2. Klasifikasi Self Confidence Siswa

\begin{tabular}{ccr}
\hline No & Klasifikasi & Presentase \\
1 & Sangat Baik & $81 \%-100 \%$ \\
2 & Baik & $61 \%-80 \%$ \\
3 & Cukup & $41 \%-60 \%$ \\
4 & Kurang Baik & $21 \%-40 \%$ \\
$\mathbf{5}$ & Tidak Baik & $\mathbf{0 \% - 2 0 \%}$ \\
\hline
\end{tabular}

Setelah menganalisis tes kemampuan koneksi matematik beserta angket self confidence siswa, selanjutnya penulis akan menarik kesimpulan dari hasil presentase tes dan angket tersebut.

\section{HASIL DAN PEMBAHASAN}

Hasil penelitian ini berdasarkan tujuan penelitian yaitu menganalisis kemampuan koneksi matematik dan self confidence siswa melalui model pembelajaran think pair share. Selain memperoleh data secara statistik mengenai hasil kemampuan koneksi matematik dalam bentuk presentase perindikator, penulis juga mendeskripsikan data presentase self confidence dari hasil penyebaran angket 19 siswa. Berikut ini adalah hasil tes tertulis kemampuan koneksi matematik dalam bentuk presentase dari masing masing indikator :

Tabel 3. Presentase Skor Indikator Tiap Butir Soal

\begin{tabular}{lcc}
\multicolumn{1}{c}{ Indikator } & No & Presentas \\
& Soal & e \\
Menggunakan koneksi antartopik matematika dan antartopik & 1 & $40,7 \%$ \\
Matematika dengan topik lain & 4 & $35,5 \%$ \\
\hline
\end{tabular}


Desimal, 2 (3), 2019 - 293

Iis Rosdianti, Nisa Fitri Alfiyah, Luvy Sylviana Zhanty

\begin{tabular}{lll}
\hline Menggunakan matematika dalam bidang studi lain dan atau & 2 & $47,3 \%$ \\
dalam kehidupan sehari-hari & 3 & $36,8 \%$ \\
\hline
\end{tabular}

Mengacu pada tabel 3, dapat kita lihat pada indikator menggunakan koneksi antartopik matematika dan antartopik matematika dengan topik lainmempunyai presentasi paling tinggi yaitu $47,3 \%$. Hal ini membuktikan bahwa indikator tersebut sudah dipahami oleh sebagian besar siswa. Namun, untuk soal ketiga dengan indikator mengkoneksikan matematika dengan kehidupan sehari-hari mengalami penurunan yang cukup besar, yaitu menjadi 36,8\%. Hal ini menandakan bahwa soal tersebut lebih sukar daripada soal sebelumnya. Pada indikator mengkoneksikan konsep antar matematika hasilnya 40,7\% sedangkan pada indikator mengkoneksikan matematika dengan disiplin ilmu lain menjadi indikator dengan presentase paling kecil yaitu $35,5 \%$. Hal ini mendandakan bahwa indikator tersebut cukup sulit bagi siswa.

Berikutnya, dari hasil penyebaran angket kepada 19 siswa diperoleh presentase dalam setiap indikator self confidence itu sendiri. Indikator self confidence menurut Hendriana dkk (2017) yang penulis gunakan adalah sebagai berikut: (1) yakin terhadap kemampuan sendiri (2) bertindak mandiri dalam mengambil keputusan (3) memiliki konsep diri yang positif (4) berani mengemukakan pendapat. Berdasarkan Tabel 4 menunjukkan bahwa hasil rata - rata dari semua inidkator yaitu cukup.

Tabel 4. Presentase Self Confidence Siswa

\begin{tabular}{ll}
\hline Indikator Self Confidence & Presentase \\
Yakin terhadap kemampuan sendiri & $57,48 \%$ \\
Bertindak mandiri dalam mengambil keputusan & $69,79 \%$ \\
Memiliki konsep diri yang positif & $58,68 \%$ \\
Berani mengemukakan pendapat & $57,87 \%$ \\
Rata-Rata Presentase & $\mathbf{6 0 , 9 6 \%}$ \\
\hline
\end{tabular}




\section{SIMPULAN DAN SARAN}

Berdasarkan hasil penelitian yang dilakukan di kelas VII A di SMP Budi Bakti Utama tahun ajaran 2018/2019 diperoleh data sebagai berikut: mengkoneksikan matematika dengan kehidupan sehari-hari mempunyai presentasi paling tinggi yaitu 47,3\%. Hal ini membuktikan bahwa indikator tersebut sudah dipahami oleh sebagian besar siswa. Namun, untuk soal ketiga dengan indikator mengkoneksikan matematika dengan kehidupan seharihari mengalami penurunan yang cukup besar, yaitu menjadi 36,8\%.

Hal ini menandakan bahwa soal tersebut lebih sukar daripada soal sebelumnya. Pada indikator mengkoneksikan konsep antar matematika hasilnya $40,7 \%$ sedangkan pada indikator mengkoneksikan matematika dengan disiplin ilmu lain menjadi indikator dengan presentase paling kecil yaitu 35,5\%. Hal ini menunjukkan bahwa kemampuan koneksi matematik melalui model pembelajaran think pair share pada siswa kelas VII A di SMP Budi Bakti Utama masih rendah. Namun, untuk skala sikap self confidence menunjukkan presentase yang cukup yaitu $60,96 \%$.

\section{DAFTAR PUSTAKA}

Adni, D. N., Nurfauziah, P., \& Rohaeti, E. E. (2018). Analisis Kemampuan Koneksi Matematis Siswa SMP Ditinjau dari Self Efficacy Siswa. JPMI.

Badjeber, R., \& Fatimah, S. (2015). Peningkatan Kemampuan Koneksi Matematis Siswa SMP Melalui Pembelajaran Inkuiri Model Alberta. Jurnal Pengajaran MIPA, 20(1), 1826.

Boleng, D. T. (2014). Pengaruh Model Pembelajaran Cooperative Script dan Think- Pair-Share terhadap Keterampilan Berpikir Kritis, Sikap
Sosial, dan Hasil Belajar Kognitif Biologi Siswa SMA Multietnis. Jurnal Pendidikan Sains, 2(2), 76-84.

Fauziah, R., Maya, R., \& Fitrianna, A. Y. (2018). Hubungan Self Confidence Terhadap Kemampuan Pemecahan Masalah Matematis Siswa SMP. Jurnal Pembelajaran Matematika Inovatif, 1(5), 881-886.

Lestari, K. E., \& Yudhanegara, M. R. (2015). Penelitian Pendidikan Matematika. Bandung: Refika Aditama.

Mahmuzah, R., Ikhsan, M., \& Yusrizal. (2014). Peningkatan Kemampuan Berpikir Kritis dan Disposisi Matematis Siswa SMP dengan Menggunakan Pendekatan Problem Posing. Jurnal Didaktik Matematika, 1(2), 43-53.

Marsitin, R. (2016). Kemampuan Penalaran Dan Koneksi Matematis Dalam Pembelajaran Matematika Dengan Problem Solving. JPM: Jurnal Pendidikan Matematika, 2(1), 58-71.

Ni'mah, A. F., Setiawani, S., \& Oktavianingtyas, E. (2017). Analisis Kemampuan Koneksi Matematika Siswa Kelas IX A MTs Negeri 1 Jember Subpokok Bahasan Kubus dan Balok. Jurnal Edukasi, 4(1), 30. https://doi.org/10.19184/jukasi.v4i1.5 087

Nursaniah, L., \& Yuspriyati, D. N. (2018). Analisis kemampuan koneksi matematik siswa smp pada materi bangun ruang sisi datar, 1(5), 857862.

Purwaningrum, J. P. (2016). Kemampuan Koneksi Matematis Siswa SD Melalui Circuit Learning. JPSD: Jurnal Pendidikan Sekolah Dasar, 2(2), 125137.

Puteri, J. W., \& Riwayati, S. (2017). Kemampuan koneksi matematis siswa pada model pembelajaran conneted mathematics project (cmp). FIBONACCI: Jurnal Pendidikan Matematika dan Matematika, 3(2), 161-168. 
Desimal, 2 (3), 2019 - 295

Iis Rosdianti, Nisa Fitri Alfiyah, Luvy Sylviana Zhanty

Rista, L., Ikhsan, M., \& Hizir. (2016). Meningkatkan Kreativitas Matematik dan Kepercayaan Diri Siswa melalui Pembelajaran Humanistik Berbasis Pendidikan Matematika Realistik. Jurnal Didaktik Matematika, 3, 1 .

Surayya, L., Subagia, I. W., \& Tika, I. N. (2014). Pengaruh Model Pembelajaran Think Pair Share Terhadap Hasil Belajar Ipa Ditinjau Dari Keterampilan Berpikir Kritis Siswa. Pengaruh Model Pembelajaran Think Pair Share Terhadap Hasil Belajar Ipa Ditinjau Dari Keterampilan Berpikir Kritis Siswa, 4, 1.

Ulya, I. F., \& Irawati, R. (2016). Peningkatan Kemampuan Koneksi Matematis Dan Motivasi Belajar Siswa Menggunakan Pendekatan Kontekstual. Pena Ilmiah, 1(1), 121130. 